\title{
Pitting Corrosion Resistance of Coloured Oxide Films Grown on Stainless Steel in Sulphuric Acid in the Presence and Absence of Chromic Acid
}

\author{
Karina O. Vasconcelos, ${ }^{a}$ Nerilso Bocchi ${ }^{*, a}$ and Alda M. Simões ${ }^{b}$ \\ ${ }^{a}$ Department of Chemistry, Universidade Federal de São Carlos, CP 676, 13560-970 São Carlos-SP, Brazil \\ ${ }^{b}$ Chemical and Biological Department, Instituto Superior Técnico, Av. Rovisco Pais, 1049-001 Lisboa Codex, Portugal
}

\begin{abstract}
Neste trabalho foi avaliada a resistência à corrosão por pites de filmes de óxidos coloridos crescidos sobre aço inoxidável AISI $304 \mathrm{em} \mathrm{H}_{2} \mathrm{SO}_{4}$ e $\mathrm{H}_{2} \mathrm{SO}_{4}+\mathrm{CrO}_{3}$. A morfologia e topografia dos filmes foram examinadas por MEV (microscopia eletrônica de varredura) e AFM (microscopia de força atômica), respectivamente. As caracterizações eletroquímicas foram conduzidas por curvas de polarização e medidas de impedância em tampão borato pH 9,2. A corrosão por pites foi avaliada por curvas de polarização realizadas na mesma solução contendo $\mathrm{NaCl}$. Todos os filmes coloridos apresentaram valores semelhantes de $E_{\text {pite }}$, mas maiores que dos filmes não coloridos. Os valores de $\left(E_{\text {pite }}-E_{\text {cor }}\right)$ resultaram no intervalo de $0,45-0,57 \mathrm{~V} ; 0,78-0,92 \mathrm{~V}$ e $0,98-1,12 \mathrm{~V}$ para filmes nativos e crescidos na presença e ausência de ácido crômico, respectivamente. Portanto, os filmes crescidos sobre o aço na ausência de ácido crômico apresentaram o maior intervalo de potencial livre de corrosão por pites.
\end{abstract}

In this work, pitting corrosion resistance of coloured oxides films grown on AISI-304 stainless-steel in $\mathrm{H}_{2} \mathrm{SO}_{4}$ and $\mathrm{H}_{2} \mathrm{SO}_{4}+\mathrm{CrO}_{3}$ was evaluated. Surface morphology and topography of the films were examined by SEM (scanning electron microscopy) and AFM (atomic force microscopy), respectively. Electrochemical characterizations were conducted by polarization curves and impedance measurements in borate buffer $\mathrm{pH}$ 9.2. The pitting corrosion was evaluated by polarization curves carried out in the same solution containing $\mathrm{NaCl}$. All coloured films presented similar values of $E_{\mathrm{pit}}$, but they were higher than those for non-coloured ones. The values of $\left(E_{\text {pit }}-E_{\text {cor }}\right)$ were in the range of $0.45-0.57 \mathrm{~V}, 0.78-0.92 \mathrm{~V}$ and $0.98-1.12 \mathrm{~V}$ for native films and films grown in the presence and absence of chromic acid, respectively. Therefore, the films grown on stainless steel in the absence of chromic acid presented the highest potential range free of pitting corrosion.

Keywords: pitting corrosion, coloured oxide films, triangular current scan method, sulphuric acid, sulphuric and chromic acids

\section{Introduction}

Coloured stainless steel has introduced a new aesthetic pattern to architecture and decoration since it has good performance in aggressive environments. These coloured oxide films can be grown on the stainless-steel surface by chemical oxidation ${ }^{1-3}$ or electrochemical oxidation. ${ }^{4-10}$ The chemical process consists of immersion in a hot, concentrated solution of chromic and sulphuric acids and leads to the formation of thick films that seem to result from the dissolution of steel and concomitant reduction of chromic acid. ${ }^{1}$ However, chromic-sulphuric acid

*e-mail: bocchi@power.ufscar.br solutions are hazardous when used at high temperatures, and therefore the use of electrochemical techniques is a potentially interesting alternative. Ogura et al. ${ }^{9}$ proposed to grow films with interference colours by applying either alternating potential pulses ${ }^{8}$ or a triangular current scans to a stainless steel substrate in chromic and sulphuric acid solution at room temperature.

However, it is well known that chromic acid contains $\mathrm{Cr}^{\mathrm{VI}}$ which is highly toxic. ${ }^{11}$ Thus far, only two distinct research groups have proposed to carry out the growth of oxide films (colouration) on stainless steel using only sulphuric acid. ${ }^{4,12-15}$ According to the methodology described by Fujimoto et al. ${ }^{4,12-14}$ specimens of type 304-stainless steel are immersed in deaerated 0.5 and $5.0 \mathrm{~mol} \mathrm{~L}^{-1} \mathrm{H}_{2} \mathrm{SO}_{4}$ at $50{ }^{\circ} \mathrm{C}$ 
and immediately submitted to a square-waves polarization for $40 \mathrm{~min}$. In the work of Zhang et al. ${ }^{15}$ samples of the same steel were coloured in $2.5 \mathrm{~mol} \mathrm{~L}^{-1} \mathrm{H}_{2} \mathrm{SO}_{4}$ at $70^{\circ} \mathrm{C}$ by applying modulated square-wave potential pulses.

As described above, the two propositions for colouring stainless steels in sulphuric acid employ electrochemical techniques under controlled-potential conditions, but in industrial applications it is much easier to control the current. So, in previous work, ${ }^{16}$ the colouration of stainless steel was investigated only in $5 \mathrm{~mol} \mathrm{~L}^{-1} \mathrm{H}_{2} \mathrm{SO}_{4}$ at different temperatures by applying triangular current scans. Thickest oxide films were formed on stainless steel samples in $5 \mathrm{~mol} \mathrm{~L}^{-1}$ $\mathrm{H}_{2} \mathrm{SO}_{4}$, kept at $50{ }^{\circ} \mathrm{C}$, using the following experimental parameters: $i_{\min }=-0.81 \mathrm{~mA} \mathrm{~cm}^{-2}, i_{\max }=1.40 \mathrm{~mA} \mathrm{~cm}^{-2}$ and $\tau=2.5 \mathrm{~s}$. The electrolysis of the steel samples carried out in these experimental conditions lead to oxide films whose thicknesses increased $(<100-280 \mathrm{~nm})$ with the electrolysis time (20-60 min). The predominant colours were gold, red and blue, although intermediate colours (greenish yellow, greenish blue and brown) were also observed, depending on the electrolysis time.

There seems to be an agreement that the corrosion resistance is increased for coloured oxide films formed on stainless steel using sulphuric acid in the presence of chromic acid. Wang et al. ${ }^{17,18}$ characterized the pitting corrosion of coloured samples obtained by chemical, INCO (chemical colouring + electrolytic hardening) and electrochemical (square-wave potential pulses) processes, using anodic polarization and electrochemical impedance spectroscopy in a $\mathrm{HCl}$ solution. Their experimental results showed that the pitting resistance of the coloured samples increased in the following process order: chemical < electrochemical < INCO. In previous work, ${ }^{19}$ it was evaluated the resistance to uniform and pitting corrosion of AISI-304 stainless-steel samples coloured by alternating potential pulses with different amplitudes and electrolysis times. All the different coloured samples were less susceptible to uniform corrosion than the non-coloured ones. A comparative study of the resistance to pitting corrosion for differently coloured AISI-304 stainless-steel samples (chemical and electrochemical methods) was also reported previously. ${ }^{20}$ It was concluded that coloured oxide films have a protective effect against pitting corrosion independently of the colouring methods under accelerated test in dearated $0.62 \mathrm{~mol} \mathrm{~L}^{-1} \mathrm{NaCl}$ solution and for the first hours of extended immersion tests in $0.40 \mathrm{~mol} \mathrm{~L}^{-1}$ $\mathrm{HCl}$ solution, when compared with non-coloured film. For longer exposition times $(8-10 \mathrm{~h})$ the non-coloured and coloured steel samples present the same behaviour.

On the other hand, for steel samples coloured in the absence of chromic acid, Fujimoto et al. ${ }^{12}$ have reported that films formed in this condition never inhibited any initiation of localised corrosion in chloride solution. From TEM (transmission electron microscopy) micrographs, these authors have concluded that the film seems to contain many pathways, which permit subsequent growth without any decrease in the rate and penetration of water and/or ions.

As highlighted hereinbefore, the colouring methods constitute an effective way of increasing the corrosion resistance and applications of stainless steel. Moreover, as far as we known there are no studies on the pitting corrosion resistance of stainless steels coloured using only sulphuric acid and the triangular current scan method. Thus, in the present work a comparative study of the pitting corrosion resistance of coloured oxides films grown by triangular current scan method in sulphuric acid with and without chromium acid is reported.

\section{Experimental}

\section{Material and electrochemical colouring}

A $150 \mathrm{~mL}$ conventional three-electrode electrochemical cell was used for colouring the stainless-steel samples, which were the working electrodes. Two spiral Pt wires were used as auxiliary electrodes, and an $\mathrm{Hg} / \mathrm{Hg}_{2} \mathrm{SO}_{4}$ electrode in a $5.0 \mathrm{~mol} \mathrm{~L}^{-1} \mathrm{H}_{2} \mathrm{SO}_{4}$ solution as reference. Stainless-steel samples $2 \times 5 \mathrm{~cm}$ in size were cut from a sheet $(0.5 \mathrm{~mm}$ thick) of bright annealed austenitic AISI304 stainless steel (ACESITA \# 2B) with the following mass composition: $\mathrm{Cr} 17.7 \%$, Ni 7.4\%, Mn 1.2\%, Si 0.4\%, $\mathrm{S} 0.01 \%, \mathrm{C} 0.07 \%$, and Fe balanced.

The stainless-steel samples were firstly degreased for $10 \mathrm{~min}$ with acetone under ultrasonic stirring and then rinsed in distilled water. After being electroreduced $\left(i=-1.0 \mathrm{~mA} \mathrm{~cm}{ }^{-2}\right.$ ) for $20 \mathrm{~min}$ in an aqueous $1.0 \mathrm{~mol} \mathrm{~L}^{-1}$ $\mathrm{HNO}_{3}$ solution, ${ }^{9}$ the pre-treated steel samples were then immersed in an aqueous $5.0 \mathrm{~mol} \mathrm{~L}^{-1} \mathrm{H}_{2} \mathrm{SO}_{4}$ solution with and without $2.5 \mathrm{~mol} \mathrm{~L}^{-1} \mathrm{CrO}_{3}$ and immediately submitted to a triangular current scan pre-programmed in the GPES software used to control an Autolab PGSTAT30 potentiostat/galvanostat from Eco Chemie. After colouring, the stainless-steel samples were removed from the solution, rinsed thoroughly with distilled water and dried in air.

The experimental parameters of the triangular current scan method used for colouring the steel samples in $5.0 \mathrm{~mol} \mathrm{~L}^{-1} \mathrm{H}_{2} \mathrm{SO}_{4}$ solution with $2.5 \mathrm{~mol} \mathrm{~L}^{-1} \mathrm{CrO}_{3}$ were the same those employed by Ogura et al. ${ }^{9}$ The current density values varied from $i_{\text {min }}=-0.81 \mathrm{~mA} \mathrm{~cm}^{-2}$ to $i_{\max }=2 \mathrm{~mA} \mathrm{~cm}^{-2}$. Electrolyses were carried out at $25^{\circ} \mathrm{C}$ for $50 \mathrm{~min}$, where films of thickness of approximately $260 \mathrm{~nm}$ were formed. 
For electrolyses carried out in an aqueous $5.0 \mathrm{~mol} \mathrm{~L}^{-1}$ $\mathrm{H}_{2} \mathrm{SO}_{4}$ solution only, the experimental parameters of the triangular current scan method were chosen following the results previously reported by Vasconcelos et al. ${ }^{16}$ The current density values varied from $i_{\text {min }}=-0.81 \mathrm{~mA} \mathrm{~cm}^{-2}$ to $i_{\max }=1.4 \mathrm{~mA} \mathrm{~cm}^{-2}$ at $50{ }^{\circ} \mathrm{C}$. In order to obtain films with comparable thickness with those grown in the presence of chromic acid, a time of electrolysis of $60 \mathrm{~min}$ were used. Films of thickness near of $240 \mathrm{~nm}$ were obtained in this case.

\section{Characterisation of the films}

The thickness of the coloured oxide films grown on the stainless-steel samples were estimated by measuring their spectral reflectance in the visible region $(400-700 \mathrm{~nm})$ using a spectra Gretag Macbeth-2180 spectrophotometer.

The surface morphology of the coloured oxide films grown by triangular current scan method in sulphuric acid with and without chromium acid was examined by scanning electron microscopy (SEM). The apparatus was the Digital Instruments IIIA. AFM images of these same films were also obtained using a Nanoscope system, operating in contact mode with a silicon tip.

\section{Electrochemical measurements}

The electrochemical studies, in order to evaluate the protective effect of the oxide films grown on the stainlesssteel samples against pitting corrosion, were conducted at room temperature by potentiodynamic polarization curves. For such, a conventional electrochemical cell with three electrodes was used. The counter electrode was a Pt-spiral and a saturated calomel electrode (SCE) was used as reference for the potential measurements. A Gamry FAS1 Femtostat potentiostat controlled by the software EIS 300 was used to obtain the polarization curves. In order to eliminate edge effects, epoxy resin was applied in all coloured samples; only one of the faces (square area of $1 \mathrm{~cm}^{2}$ ) was not covered. The coloured samples were immersed in an aqueous borate buffer solution of pH 9.2 [0.050 $\mathrm{mol} \mathrm{L}^{-1} \mathrm{H}_{3} \mathrm{BO}_{3}$ (Merck p.a.) + $0.075 \mathrm{~mol} \mathrm{~L}^{-1}$ $\mathrm{Na}_{2} \mathrm{~B}_{4} \mathrm{O}_{7} \cdot 10 \mathrm{H}_{2} 0$ (Riedel-de Haen analytical reagent)] without and with $0.7 \mathrm{~mol} \mathrm{~L}^{-1} \mathrm{NaCl}$ (Panreac), at room temperature, and kept at the open circuit potential. After the corrosion potential was practically stable ( $c a .40 \mathrm{~min})$, the steel sample was polarized to more negative of $c a .30 \mathrm{mV}$ than the corrosion potential. The potentiodynamic polarization curve was then immediately initiated in the anodic direction (up to $c a .1 .1 \mathrm{~V} v s$. SCE) at a sweep rate of $1 \mathrm{mV} \mathrm{s}^{-1}$. At least three polarization curves were always obtained for each one of the steel samples electrolysed in a given experimental condition. The results were normalized to the geometrical area of the samples.

EIS (electrochemical impedance spectroscopy) measurements were also conducted for the colouredsteel samples in borate buffer solution $\mathrm{pH} 9.2$ containing $0.7 \mathrm{~mol} \mathrm{~L}^{-1} \mathrm{NaCl}$. These measurements were obtained at the open circuit potential, applying a $10 \mathrm{mV}$ (rms) ac signal and scanning the $100 \mathrm{kHz}-10 \mathrm{mHz}$ frequency range. The analysis was performed in Gamry FAS1 Femtostat potentiostat controlled by the software EIS 300. The results were also normalized to the samples geometrical area.

\section{Results and Discussion}

Typical potentiodynamic polarization curves, obtained in borate buffer $\mathrm{pH} 9.2$ for steel samples in the three situations investigated (as received and coloured in the presence and absence of chromic acid), are shown in Figure 1. Comparing two of these curves (a and c) with those previously reported ${ }^{21}$ two main differences are observed for potentials lower than $0.6 \mathrm{~V} v s$. ECS. The curves in Figure 1 present lower values of current density and higher values of corrosion potential. This possibly occurs because the edge effects were eliminated by applying epoxy resin in the steel samples. Therefore, the oxide films (native and grown on steel samples) are more protective in the present work. Among the curves in Figure 1, the values of current density are higher for coloured than non-coloured samples for the same overpotential in the passive region (see values of $-\log i$ for $\eta=0.2 \mathrm{~V}$ in the figure). The increases in the values of current density are close to one and two order of magnitude for steel samples coloured in $\mathrm{H}_{2} \mathrm{SO}_{4}$ and $\mathrm{H}_{2} \mathrm{SO}_{4}$

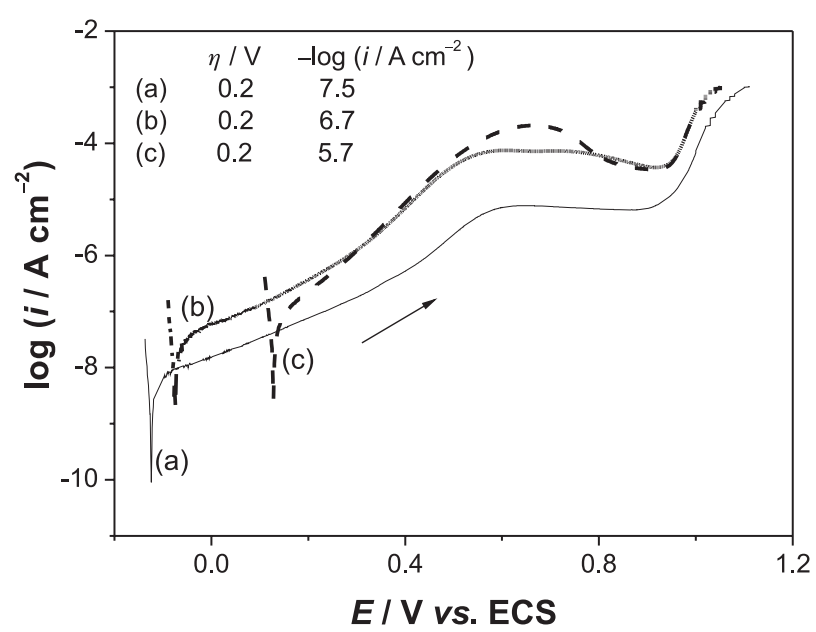

Figure 1. Typical potentiodynamic polarization curves $\left(v=1 \mathrm{mV} \mathrm{s}^{-1}\right)$ obtained at room temperature in a borate buffer solution $\mathrm{pH} 9.2$ for AISI-304 stainless-steel (a) non-coloured sample (as received) and previously coloured samples using the triangular current scans method in (b) $5.0 \mathrm{~mol} \mathrm{~L}^{-1} \mathrm{H}_{2} \mathrm{SO}_{4}$ and (c) $5.0 \mathrm{~mol} \mathrm{~L}^{-1} \mathrm{H}_{2} \mathrm{SO}_{4}+2.5 \mathrm{~mol} \mathrm{~L}^{-1} \mathrm{CrO}_{3}$. 
$+\mathrm{CrO}_{3}$, respectively. These results indicate that oxide films with distinct surface areas were grown on the steel surface. So, the oxide films grown in $\mathrm{H}_{2} \mathrm{SO}_{4}+\mathrm{CrO}_{3}$ have more surface area than those grown in only $\mathrm{H}_{2} \mathrm{SO}_{4}$. Figure 2 shows typical micrographs obtained for steel samples in the three situations investigated (as received and coloured in the presence and absence of chromic acid). A compact and uniform oxide film is spontaneously formed on steel surface (Figure 2a). On the other hand, highly porous
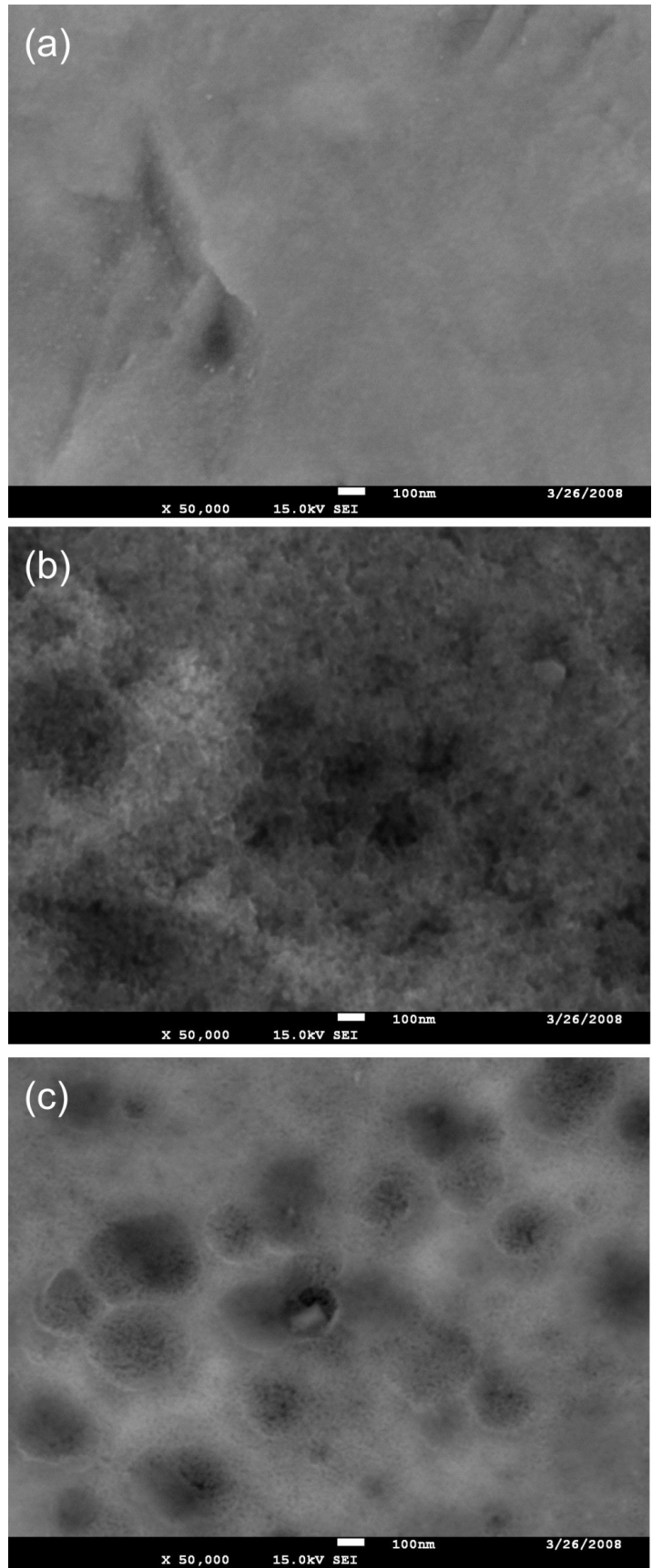

Figure 2. Typical micrographs obtained by SEM for AISI-304 stainlesssteel (a) non-coloured (as received) and previously coloured samples using the triangular current scans method in (b) $5.0 \mathrm{~mol} \mathrm{~L}^{-1} \mathrm{H}_{2} \mathrm{SO}_{4}$ and (c) $5.0 \mathrm{~mol} \mathrm{~L}^{-1} \mathrm{H}_{2} \mathrm{SO}_{4}+2.5 \mathrm{~mol} \mathrm{~L}^{-1} \mathrm{CrO}_{3}$. films are grown on steel by the triangular current scan method (Figures $2 b$ and c). However, these figures do not distinguish differences in porosity between oxide films grown in $\mathrm{H}_{2} \mathrm{SO}_{4}$ with and without $\mathrm{CrO}_{3}$. Kikuti et al. ${ }^{21}$ have also observed by SEM the growth of highly porous oxide films in $\mathrm{H}_{2} \mathrm{SO}_{4}+\mathrm{CrO}_{3}$ when the triangular current scan method was employed. Figure 3 presents typical surface topographies obtained for steel samples in the three
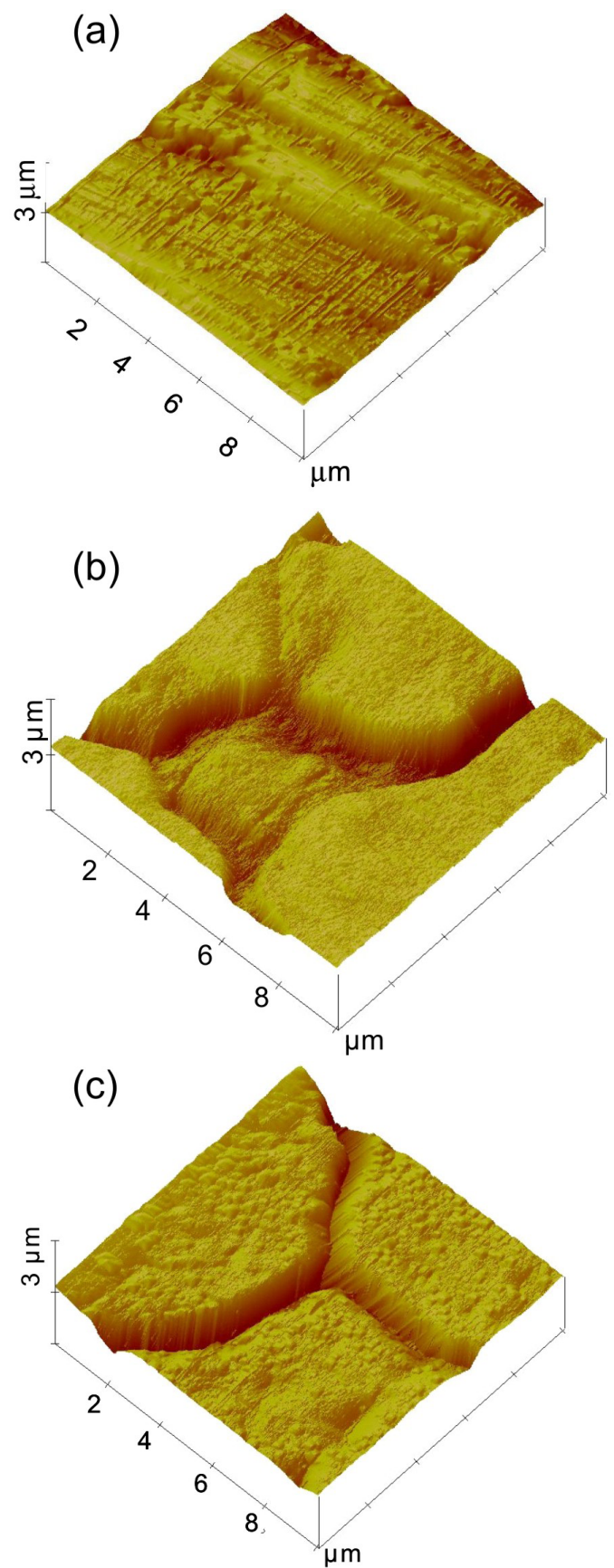

Figure 3. Typical surface topographies obtained by AFM for AISI-304 stainless-steel (a) non-coloured (as received) and previously coloured samples using the triangular current scans method in (b) $5.0 \mathrm{~mol} \mathrm{~L}^{-1} \mathrm{H}_{2} \mathrm{SO}_{4}$ and (c) $5.0 \mathrm{~mol} \mathrm{~L}^{-1} \mathrm{H}_{2} \mathrm{SO}_{4}+2.5 \mathrm{~mol} \mathrm{~L}^{-1} \mathrm{CrO}_{3}$. 
situations investigated (as received and coloured in the presence and absence of chromic acid). From roughness analysis in various AFM images of different sizes $\left(100 \mu \mathrm{m}^{2}\right.$, $2,500 \mu \mathrm{m}^{2}$ and $10,000 \mu \mathrm{m}^{2}$ ) the films grown either in $\mathrm{H}_{2} \mathrm{SO}_{4}$ or $\mathrm{H}_{2} \mathrm{SO}_{4}+\mathrm{CrO}_{3}$ reveal surface areas 6-20\% higher than AFM image areas; whereas oxide films spontaneously formed on steel present surface areas of 3-5\% higher than AFM image areas. Therefore, only differences in porosity may explain why oxide films grown in $\mathrm{H}_{2} \mathrm{SO}_{4}+\mathrm{CrO}_{3}$ have more surface area than those grown in only $\mathrm{H}_{2} \mathrm{SO}_{4}$ as observed by polarization curves (Figure 1).

The pitting corrosion susceptibility of the oxide films formed on the stainless-steel samples in the three situations (as received and grown in the presence and absence of chromic acid) was evaluated by potentiodynamic polarization curves carried out in a borate buffer solution pH 9.2, containing chloride ions (Figure 4). After these measurements, the visual colour of all steel samples was practically unchanged. As already pointed out in Figure 1, the values of current density are also higher for coloured (near one order of magnitude) than non-coloured samples for the same overpotential in the passive region. The values of $E_{\text {cor }}, E_{\text {pit }}$ and $\left(E_{\mathrm{pit}}-E_{\mathrm{cor}}\right)$ extracted from the potentiodynamic polarization curves of Figure 4 for steel samples non-coloured and previously coloured using the triangular current scan method are listed in Table 1. All coloured steel samples present similar values of $E_{\text {pit }}$ but they are higher than those for non-coloured ones. By the other hand, the values of $\left(E_{\text {pit }}-E_{\text {cor }}\right)$ are in the range of $0.45 \mathrm{~V}-0.57 \mathrm{~V}, 0.78 \mathrm{~V}-0.92 \mathrm{~V}$ and $0.98 \mathrm{~V}-1.12 \mathrm{~V}$ for native films (very thin films) and films grown (thicker films) in the presence and absence of chromic acid, respectively. These

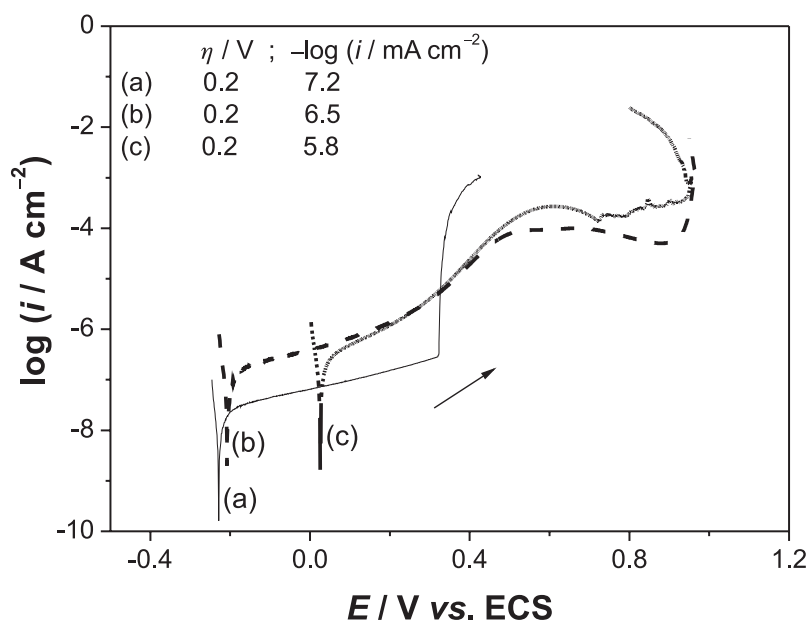

Figure 4. Typical potentiodynamic polarization curves $\left(v=1 \mathrm{mV} \mathrm{s}^{-1}\right)$ obtained at room temperature in a borate buffer solution $\mathrm{pH} 9.2$ containing $0.7 \mathrm{~mol} \mathrm{~L}^{-1} \mathrm{NaCl}$ for AISI-304 stainless-steel (a) noncoloured sample (as received) and previously coloured samples using the triangular current scans method in (b) $5.0 \mathrm{~mol} \mathrm{~L}^{-1} \mathrm{H}_{2} \mathrm{SO}_{4}$ and (c) $5.0 \mathrm{~mol} \mathrm{~L}^{-1} \mathrm{H}_{2} \mathrm{SO}_{4}+2.5 \mathrm{~mol} \mathrm{~L}^{-1} \mathrm{CrO}_{3}$. results show that the films grow on stainless steel in the absence of chromic acid present the highest potential range free of pitting corrosion. So, the films grown on stainless steel in this condition are more protective against pitting corrosion. A possible explanation for these results can be given assuming that the porous of coloured films are of the isolated type, i.e. the porous begin in the top of the films but do not reach the steel substrat. ${ }^{22}$ Moreover, oxide films with lower porous density may also possibly explain the results for films grown in $\mathrm{H}_{2} \mathrm{SO}_{4}$, as they represent a greater physical barrier. Less porosity leads to less free pathways for penetration of water and ions and so, less pitting corrosion susceptibility.

Table 1. Values of $E_{\text {cor }}, E_{\text {pit }}$ and $\left(E_{\text {pit }}-E_{\text {cor }}\right)$ from potentiodynamic polarization curves obtained in borate buffer solution $\mathrm{pH} 9.2+0.7 \mathrm{~mol} \mathrm{~L}^{-1}$ $\mathrm{NaCl}$ for AISI-304 stainless-steel non-coloured and previously coloured samples using the triangular current scan method

\begin{tabular}{lccc}
\hline & $E_{\text {cor }} / \mathrm{V}$ & $E_{\text {pit }} / \mathrm{V}$ & $\left(E_{\text {pit }}-E_{\text {cor }} / \mathrm{V}\right.$ \\
\hline Native films & -0.217 & 0.326 & 0.543 \\
& -0.228 & 0.223 & 0.451 \\
& -0.205 & 0.368 & 0.573 \\
Films grown in $\mathrm{H}_{2} \mathrm{SO}_{4}$ & -0.184 & 0.935 & 1.119 \\
& -0.200 & 0.779 & 0.979 \\
& -0.206 & 0.907 & 1.113 \\
Films grown in $\mathrm{H}_{2} \mathrm{SO}_{4}+\mathrm{CrO}_{3}$ & 0.024 & 0.949 & 0.925 \\
& 0.048 & 0.941 & 0.893 \\
& 0.052 & 0.830 & 0.778 \\
\hline
\end{tabular}

As shown in Figure 5, impedance spectra were also obtained at the open circuit potential in borate buffer $\mathrm{pH} 9.2$ containing $0.7 \mathrm{~mol} \mathrm{~L}^{-1} \mathrm{NaCl}$ for steel samples in the three situations investigated (as received and coloured in the presence and absence of chromic acid). It is important to mention that these impedance spectra are similar those obtained at the same buffer solution in the absence of chloride ions. ${ }^{21}$ As previously reported, the impedance response of the films was also capacitive for most of the spectrum.

Like in a previous work, ${ }^{21}$ the fitting of capacitive part of the spectra was also made using a constant phase element $(\mathrm{CPE})$, whose impedance is given by:

$$
Z_{C P E}=\frac{1}{Y_{0}(j w)^{n}}
$$

where $w$ is the angular frequency, $Y_{0}$ the frequencyindependent parameter, $n$ related to the phase angle and gives information on the type of element ( $n=1$ for a capacitor and $n=0$ for a resistor) and $j=(-1)^{1 / 2}$. For native films and films grown in the presence and absence of chromic acid, the equivalent circuit (EC) as well as the results of the fitting is presented in Figure 5 and Table 2. The values of $Y_{0}$ were 
practically the same for native film and film grown in $\mathrm{H}_{2} \mathrm{SO}_{4}$ Unlikely, the value of $Y_{0}$ for the film grown in $\mathrm{H}_{2} \mathrm{SO}_{4}+\mathrm{CrO}_{3}$ was more than one order of magnitude higher than those of

(a)
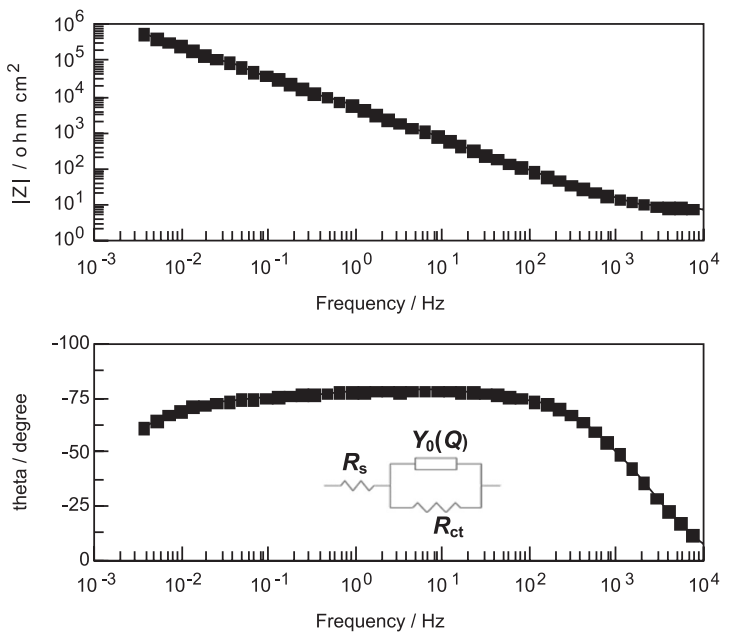

(b)
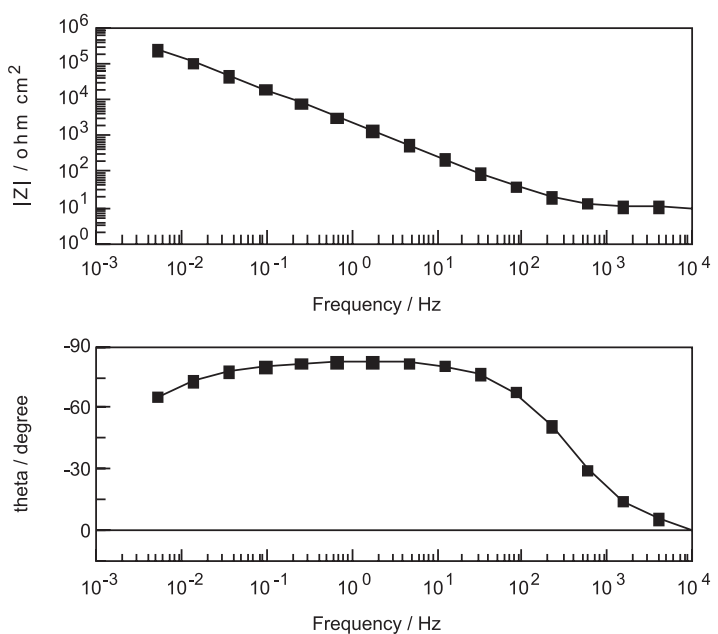

(c)
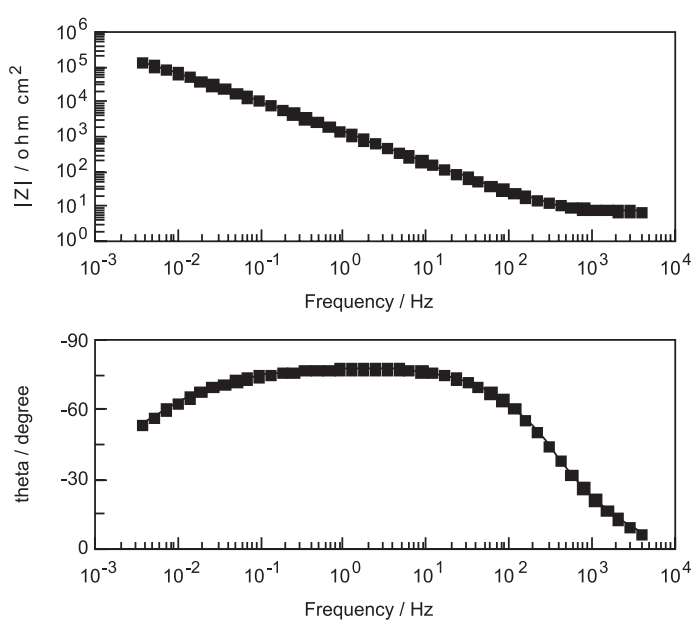

Figure 5. Impedance spectra obtained at the open circuit potential and room temperature in a borate buffer solution $\mathrm{pH} 9.2$ containing $0.7 \mathrm{~mol} \mathrm{~L}^{-1}$ $\mathrm{NaCl}$ for AISI-304 stainless-steel (a) non-coloured sample (as received) and previously coloured samples using the triangular current scans method in (b) $5.0 \mathrm{~mol} \mathrm{~L}^{-1} \mathrm{H}_{2} \mathrm{SO}_{4}$ and (c) $5.0 \mathrm{~mol} \mathrm{~L}^{-1} \mathrm{H}_{2} \mathrm{SO}_{4}+2.5 \mathrm{~mol} \mathrm{~L}^{-1} \mathrm{CrO}_{3}$.
Table 2. Values used in the fitting of EIE spectra

\begin{tabular}{lcccc}
\hline & $\begin{array}{c}Y_{0}(\mathrm{Q}) / \\
\left(\mathrm{F} \mathrm{cm}^{-2} \mathrm{~s}^{-\mathrm{n}}\right)\end{array}$ & $n$ & $\begin{array}{c}R_{\mathrm{ct}} / \\
\left(\Omega \mathrm{cm}^{2}\right)\end{array}$ & $X^{2}$ \\
\hline Native films & $4.0 \times 10^{-5}$ & 0.87 & $1.6 \times 10^{6}$ & $2.1 \times 10^{-3}$ \\
Films grown in $\mathrm{H}_{2} \mathrm{SO}_{4}$ & $8.4 \times 10^{-5}$ & 0.92 & $7.5 \times 10^{5}$ & $2.2 \times 10^{-3}$ \\
Films grown in & $1.5 \times 10^{-4}$ & 0.86 & $2.7 \times 10^{5}$ & $1.8 \times 10^{-3}$ \\
$\mathrm{H}_{2} \mathrm{SO}_{4}+\mathrm{CrO}_{3}$ & & & & \\
\hline
\end{tabular}

the other films. Since there was no change in the equivalent circuit of the spectrum and the value of $Y_{0}$ is proportional to the area, this increase suggests that the area contributing to the values of $Y_{0}$ has increased. The area increase can be explained by an increased surface area in the film, i.e., by the thickness of a more porous film, as suggested hereinbefore. The fact that there is only one time constant in the spectrum also suggests identical properties for the walls and the bottom of the pores.

$R_{\mathrm{ct}}$ accounts for the charge transfer resistance at the film surface. Its estimate is affected by a relatively high error since its response comes mostly below the low frequency of the spectrum. In spite of this, the fact that it decreases for films grown in $\mathrm{H}_{2} \mathrm{SO}_{4}+\mathrm{CrO}_{3}$ is in agreement with the development of an extended area. These results indicate that the porosity of the films grown on stainless steel by the triangular current scan method increases with $\mathrm{CrO}_{3}$ addition, which corroborates the interpretation given for the obtained results of pitting corrosion.

\section{Conclusions}

Thick passive films showing interference colours have been grown on stainless steel in aqueous solution of $5.0 \mathrm{~mol} \mathrm{~L}^{-1} \mathrm{H}_{2} \mathrm{SO}_{4}$ and $5.0 \mathrm{~mol} \mathrm{~L}^{-1} \mathrm{H}_{2} \mathrm{SO}_{4}+2.5 \mathrm{~mol} \mathrm{~L}^{-1} \mathrm{CrO}_{3}$ by the triangular current scan method. Films of thickness near of $240 \mathrm{~nm}$ and $260 \mathrm{~nm}$ were formed in $\mathrm{H}_{2} \mathrm{SO}_{4}\left(\right.$ at $50^{\circ} \mathrm{C}$ ) and $\mathrm{H}_{2} \mathrm{SO}_{4}+\mathrm{CrO}_{3}$ (at $25^{\circ} \mathrm{C}$ ), respectively. All coloured films presented similar values of $E_{\text {pit }}$ but they were higher than those for non-coloured ones. The values of $\left(E_{\text {pit }}-E_{\text {cor }}\right)$ were in the range of $0.45-0.57 \mathrm{~V}, 0.78-0.92 \mathrm{~V}$ and $0.98-1.12 \mathrm{~V}$ for native films and films grown in the presence and absence of chromic acid, respectively. Therefore, the films grown on stainless steel in the absence of chromic acid presented the highest potential range free of pitting corrosion. This was explained by a film formation with lower number of porous as suggested by impedance measurements.

\section{Acknowledgements}

The authors gratefully acknowledge the Brazilian research funding agencies FAPESP, CNPq and CAPES for 
the financial support of this work. The authors also thank Prof. Dr. Rodrigo del Rio from Pontifícia Universidad Católica de Chile for the AFM images.

\section{References}

1. Evans, T. E.; Hart, A. C.; James, H.; Smith, V. A.; Trans. Inst. Met. Finish. 1972, 51, 108.

2. Evans, T. E.; Corros. Sci. 1977, 17, 105.

3. Evans, T. E.; Hart, A. C.; Skedgell, A. E.; Trans. Inst. Met. Finish. 1973, 50, 77.

4. Fujimoto, S.; Shibata, T.; Wada, K.; Tsutae, T.; Corros. Sci. 1993, 35, 147.

5. Lin, C. J.; Duh, J. G.; Surf. Coat. Technol. 1994, 70, 79.

6. Lin, C. J.; Duh, J. G.; Surf. Coat. Technol. 1995, 73, 52.

7. Lin, C. J.; Duh, J. G.; Surf. Coat. Technol. 1996, 85, 175.

8. Ogura, K.; Sakurai, K.; Uehara, S.; J. Electrochem. Soc. 1994, 141,648 .

9. Ogura, K.; Lou, W.; Nakayama, M.; Electrochim. Acta 1996, $41,2849$.

10. Ogura, K.; Tsujigo, M.; Sakurai, K.; Yano, J.; J. Electrochem. Soc. 1993, 140, 1311.

11. Rajeshwar, K.; Ibanez, J. G.; Environmental Electrochemistry, Academic Press: San Diego, 1997.

12. Fujimoto, S.; Shibata, T.; Mater. Sci. Forum 1995, 185, 741.
13. Fujimoto, S.; Kiyoshi, T.; Shibata, T.; J. Electroanal. Chem. 1999, 473, 265.

14. Fujimoto, S.; Kawachi, S.; Nishio, T.; Shibata, T.; Electrochim. Acta 2001, 47, 543.

15. Zhang, J. X.; Chen, J.; Qiao, Y. N.; Cao, C. N.; Trans. Inst. Met. Finish. 1999, 77, 106.

16. Vasconcelos, K. O.; Bocchi, N.; Rocha, R. C.; Biaggio, S. R.; J. Electrochem. Soc. 2005, 152, B491.

17. Wang, J. H.; Duh, J. G.; Shih, H. C.; J. Mater. Sci. Lett. 1995, 14,53 .

18. Wang, J. H.; Duh, J. G.; Shih, H. C.; Surf. Coat. Technol. 1996, $78,248$.

19. Conrrado, R.; Bocchi, N.; Rocha-Filho, R. C.; Biaggio, S. R.; Electrochim. Acta 2003, 48, 2417.

20. Kikuti, E.; Conrrado, R.; Bocchi, N.; Biaggio, S. R.; RochaFilho, R. C.; Electrochim. Acta 2004, 15, 472.

21. Kikuti, E.; Bocchi, N.; Pastol, J. L.; Ferreira, M. G.; Montemor, M. F.; Da Cunha Belo, M.; Simões, A. M.; Corr. Sci. 2007, 49, 2303.

22. Kutzelnigg, A.; Plating 1961, 48, 382.

Received: April 30, 2009

Web Release Date: December 3, 2009

FAPESP helped in meeting the publication costs of this article. 